\title{
Central Bank Currency Swaps and Their Implications to the International Financial Reform
}

Xu Mingqi

\begin{abstract}
Since the outbreak of the global financial crisis, a series of currency swap arrangements among central banks have been reached, and many short-term ad hoc mechanisms have been later transformed into permanent institutions, with the decentralized role of the USD and increasing significance of other currencies. It is important to note, however, that currency swaps by Western countries are generally not intended to reform but to maintain stability of the U.S.-dominated international financial system and the USD hegemony. The comprehensive currency swap arrangements made among six major developed economies since the financial crisis exemplify their resistance to the international financial reform. Meanwhile, developing countries have also laid out their own blueprints, highlighted by China's currency swap arrangements with 33 foreign central banks and the accelerating RMB internationalization.
\end{abstract}

Xu Mingqi is Research Professor of International Economics at the Shanghai Academy of Social Sciences and President of the Shanghai Institute for European Studies. Mailing Address: Institute of World Economy, Shanghai Academy of Social Sciences, No. 7, Lane 622, Middle Huaihai Road, Shanghai 200020, China. He can also be reached atxmq@sass. org.cn. The author would like to thank the Shanghai Development Foundation for its financial support for this study.

(c) 2016 World Century Publishing Corporation and Shanghai Institutes for International Studies China Quarterly of International Strategic Studies, Vol. 2, No. 1, 135-152

DOI: $10.1142 / S 2377740016500044$ 
The currency swaps promoted by the People's Bank of China (PBOC) between the RMB and other currencies would inject supplementary liquidity to a turbulent market and offset impact from the selective currency swaps of the U.S. Federal Reserve, thus proving beneficial to developing countries. While such currency swaps are far from replacing the IMF's role in stabilizing the global financial market, they are posing both challenges and new opportunities to the reform of the international financial system.

Keywords: Currency swap; USD hegemony; IMF; RMB internationalization; international financial reform.

Despite the stalling pace of the international financial reform, currency swap arrangements among central banks have been on a rapid rise. In the past decade, a lot of currency swap arrangements have been reached globally. For example, China has joined the bilateral swap agreements between the USD and other national currencies extended under the Chiang Mai Initiative (CMI) since the early 2000s; China and South Korea reached a currency swap agreement in 2008 based on the "10+3" (ASEAN plus China, Japan and South Korea) mechanism; central banks of six Western economies (the U.S., Switzerland, the UK, Canada, Japan, and European Central Bank) headed by the U.S. Federal Reserve extended their original swap arrangement in October 2013 with no quota and no time limits - to name just a few. What are the implications of such currency swap arrangements to the international financial system? To what extent will they contribute to the ongoing international financial reform, in all likelihood resulting in a decentralized role of the USD and increasingly significance of other currencies such as the RMB?

\section{Central Bank Currency Swaps: A Retrospective Analysis}

The concept of currency swaps originated from that of foreign exchange swaps. A foreign exchange swap, or FX swap, refers to the transaction between two or more parties normally exchanging spot foreign exchange for forward foreign exchange through contract, while a currency swap is for various parties to exchange their own currencies or act together for different terms of other foreign currencies. The original purpose of both FX swaps and currency swaps is to avoid turbulence and other risks on 
the foreign exchange market, and these transactions are usually made by commercial banks, with exporters and other international business practitioners as clients. Yet gradually, currency swaps have been used for other purposes as well. A most outstanding case took place before 2008, which was the currency swap between the Greek government and Goldman Sachs, intended to reduce the government deficit and debt scale of Greece.

Currency swaps of central banks can also be regarded as a means to provide standby credit for relevant countries, in which one country uses its national currency to exchange for that of the other or even a third country. Therefore, a currency swap agreement may be either bilateral or multilateral. In general, some conditions or terms are formulated in the agreement. For instance, when Party A, by contract, seeks to exchange its domestic currency for the national currency of Party B or certain foreign currency provided by Party B, the latter should do so according to their agreed conditions or terms. Such currency swap agreements are normally signed between central banks of different countries.

The earliest currency swap between central banks dates back to the Bretton Woods era when, on February 28, 1962, the U.S. Federal Reserve and the Central Bank of France signed a currency swap agreement which took effect on March 1, for the U.S. was urging European countries to intervene in the foreign exchange market to maintain stability of the USD exchange rate. By this agreement the Central Bank of France credited 500 million Francs into the U.S. Federal Reserve account, while the Federal Reserve credited US\$50 million into the account of the Central Bank of France. This swap was initially a short-term one only valid for three months. However, with the worsening of the USD crisis, the U.S. expanded the scale of its swap transactions to include Austria, Belgium, Britain, Germany, Italy, Holland, Switzerland, Canada and several other countries, with a total credit amount of swaps of $\$ 900$ million by 1963 . Even after the U.S. announcement of abandoning the USD-Gold linkage in August 1971, the amount of currency swaps between the U.S. and European countries continued rising. By the mid-1970s, the amount had soared to $\$ 20$ billion. The currency swaps during the Bretton Woods era embraced the obvious purpose of saving the U.S. from its dollar crisis, and served as a cooperative means to suppress the trend of underselling the USD and buying other currencies. 
In parallel, the IMF-sponsored General Arrangement to Borrow (GAB) was signed in 1962. To further mitigate the dollar crisis, the IMF facilitated another agreement among the U.S., Britain, Germany, France, Japan, Belgium, Holland, Canada and Sweden under the GAB framework. According to this complementary agreement, the IMF, if in need, could borrow money from the above countries with an initial quota of $\$ 6$ billion, and the quota could be constantly increased. Up until 1983, the quota had reached SDR 17 billion. The GAB agreement provided another kind of standby credit and was certainly different from currency swap agreements between central banks, although both were employed to cope with the dollar crisis.

After the collapse of the Bretton Woods system, strong foreign exchanges were much more needed by most countries to stabilize their domestic markets in the enduring financial crisis. Although the IMF still kept its obligation to extend short-term credit to those in need, it could hardly meet their demands. Currency swaps of central banks thus became a new approach to deal with market shocks, with swap funds included into the standby foreign exchange reserve. ${ }^{1}$ As an emergent

Currency swaps among the U.S.' and European central banks in the Bretton Woods era were mainly intended to stabilize the global US dollar market. measure of market intervention, the scale and term of currency swaps are usually limited. For example, shortly after the 9/11 terrorist attacks in 2001, the U.S. Federal Reserve signed 30-day temporary currency swap agreements with the European Central Bank, Bank of England, and Bank of Canada in order to prevent the expected market turmoil.

A new round of massive currency swaps among central banks did not appear until the outbreak of global financial crisis in 2008. Virtually at the outset of the crisis, the Federal Reserve signed currency swap agreements separately with the European Central Bank ( $\$ 20$ billion) and Switzerland National Bank ( $\$ 4$ billion). By the end of September 2008, the Federal Reserve had signed seven agreements with the European Central Bank and

${ }^{1}$ Maurice Obstfeld, Jay C. Shambaugh, and Alan M. Taylor, “Financial Instability, Reserves and Central Bank Swap Lines in the Panic of 2008," American Economic Review, Vol. 99, No. 2 (May 2009), pp. 480-486. 
Switzerland National Bank, with a total amount of $\$ 240$ billion and $\$ 60$ billion in credit respectively. The Federal Reserve and seven other central banks of Western countries, namely, Bank of Canada ( $\$ 30$ billion), Bank of Japan ( $\$ 120$ billion), Bank of England ( $\$ 80$ billion), National Bank of Denmark (\$150 billion), Norges Bank (Norwegian central bank, $\$ 15$ billion), Reserve Bank of Australia (\$30 billion) and Sveriges Riksbank (Swedish central bank, $\$ 10$ billion), also signed bilateral currency swap agreements with an overall amount of $\$ 620$ billion. By October 29, 2008, 14 countries had signed currency swap agreements with the U.S. and the swap amount further rose up to $\$ 850$ billion, four times ${ }^{2}$ as much as the IMF gross assets (See Table 1). These currency swap agreements were set to expire in February 2010, and were not renewed afterwards thanks to the early recovery of the international financial market.

Unfortunately, the European debt crisis quickly followed as another market disaster that required urgent action from the international community, and injecting liquidity to European countries became unavoidable. In May 2010, the U.S. Federal Reserve signed new three-year currency swap agreements with the Bank of Canada, Bank of England, the European Central Bank, Bank of Japan and Switzerland National Bank. When this agreement was about to expire on October 31, 2013, the six central banks announced that they would extend it to longer terms with an indefinite limit of amounts. Since then, the nature of temporary liquidity provided by currency swaps of central banks has undergone a fundamental change, resulting in the creation of a prototype of a new international monetary system. ${ }^{3}$

Another case is the currency swap of ASEAN central banks. Five members of ASEAN countries ${ }^{4}$ signed currency swap agreements in 1977,

${ }^{2}$ These 14 central banks are: Reserve Bank of Australia, Central Bank of Brazil, Bank of Canada, Danish National Bank, Bank of England, European Central Bank, Bank of Japan, Bank of Korea, BANCO DE MEXICO, New Zealand Reserve Bank, Norwegian Central Bank, Monetary Authority of Singapore, Sveriges Riksbank (Sweden), and Switzerland National Bank.

${ }^{3}$ Li Yang, "Yige dui Zhongnanhai Butai Youhao de Jingji Tongmeng zheng Xingcheng [An Economic Union Unfriendly to Zhongnanhai is Forming]," Boxun News, December 9, 2013, www.boxun.com/news/gb/pubvp/2013/12/201312190619.shtml.

${ }^{4}$ These 5 ASEAN members are Indonesia, Malaysia, the Philippines, Singapore, and Thailand. 
Table 1. Currency Swap Agreements Signed by the U.S. Federal Reserve Since the 2008 Global Financial Crisis.

\begin{tabular}{|c|c|c|c|}
\hline Time of Announcement & $\begin{array}{c}\text { Participating Central } \\
\text { Banks }\end{array}$ & Amount & Term \\
\hline December 12, 2007 & $\begin{array}{l}\text { European Central Bank } \\
\text { Switzerland National Bank }\end{array}$ & $\begin{array}{l}\$ 20 b \text {. } \\
\$ 4 b \text {. }\end{array}$ & 6 months \\
\hline March 11, 2008 & $\begin{array}{l}\text { European Central Bank } \\
\text { Switzerland National Bank }\end{array}$ & $\begin{array}{l}\text { Expanded to } \$ 30 \mathrm{~b} \text {. } \\
\text { Expanded to } \$ 6 \mathrm{~b} \text {. }\end{array}$ & \\
\hline May 2, 2008 & $\begin{array}{l}\text { European Central Bank } \\
\text { Switzerland National Bank }\end{array}$ & $\begin{array}{l}\text { Expanded to } \$ 50 \mathrm{~b} \text {. } \\
\text { Expanded to } \$ 12 \mathrm{~b} \text {. }\end{array}$ & $\begin{array}{l}\text { Extended to } \\
\text { January 30, } \\
2009\end{array}$ \\
\hline July 30, 2008 & European Central Bank & Expanded to $\$ 55 b$. & $\begin{array}{l}84 \text { days' tender } \\
\text { period }\end{array}$ \\
\hline September 18, 2008 & $\begin{array}{l}\text { European Central Bank } \\
\text { Switzerland National Bank } \\
\text { Bank of Japan } \\
\text { Bank of England } \\
\text { Bank of Canada }\end{array}$ & $\begin{array}{l}\text { Expanded to } \$ 110 \mathrm{~b} \text {. } \\
\text { Expanded to } \$ 27 \mathrm{~b} \text {. } \\
\$ 60 \mathrm{~b} \text {. (Newly signed) } \\
\$ 40 \mathrm{~b} \text {. (Newly signed) } \\
\$ 10 \mathrm{~b} \text {. (Newly signed) }\end{array}$ & $\begin{array}{l}\text { Tender period } \\
\text { of one } \\
\text { month and } \\
\text { three } \\
\text { months }\end{array}$ \\
\hline September 24, 2008 & $\begin{array}{l}\text { Reserve Bank of Australia } \\
\text { Dammars National bank } \\
\text { Sveriges Riksbank } \\
\text { Norges Central Bank }\end{array}$ & $\begin{array}{l}\text { \$10b. (Newly signed) } \\
\$ 5 \mathrm{~b} \text {. (Newly signed) } \\
\text { \$10b. (Newly signed) } \\
\text { \$5b. (Newly signed) }\end{array}$ & $\begin{array}{l}\text { Tender period } \\
\text { of one } \\
\text { month and } \\
\text { three } \\
\text { months }\end{array}$ \\
\hline September 26, 2008 & $\begin{array}{l}\text { European Central Bank } \\
\text { Switzerland National Bank }\end{array}$ & $\begin{array}{l}\text { Expanded to } \$ 120 \mathrm{~b} \text {. } \\
\text { Expanded to } \$ 30 \mathrm{~b} \text {. }\end{array}$ & \\
\hline September 28, 2008 & $\begin{array}{l}\text { European Central Bank } \\
\text { Switzerland National Bank } \\
\text { Bank of Canada } \\
\text { Bank of England } \\
\text { Bank of Japan } \\
\text { Dammars National bank } \\
\text { Norges Central Bank } \\
\text { Reserve } \\
\text { Bank of Australia } \\
\text { Sveriges Riksbank }\end{array}$ & $\begin{array}{l}\text { Expanded to } \$ 240 \mathrm{~b} \text {. } \\
\text { Expanded to } \$ 60 \mathrm{~b} \text {. } \\
\text { Expanded to } \$ 30 \mathrm{~b} \text {. } \\
\text { Expanded to } \$ 80 \mathrm{~b} \text {. } \\
\text { Expanded to } \$ 120 \mathrm{~b} \text {. } \\
\text { Expanded to } \$ 15 \mathrm{~b} \text {. } \\
\text { Expanded to } \$ 15 \mathrm{~b} \text {. } \\
\text { Expanded to } \$ 30 \mathrm{~b} \text {. } \\
\text { Expanded to } \$ 30 \mathrm{~b} \text {. }\end{array}$ & \\
\hline October 13, 2008 & $\begin{array}{l}\text { European Central Bank } \\
\text { Switzerland National Bank } \\
\text { Bank of England } \\
\text { Bank of Japan }\end{array}$ & Amount as required & $\begin{array}{l}\text { Extended to } \\
\text { April 30, } \\
2009\end{array}$ \\
\hline October 14, 2008 & Bank of Japan & Scale-up as required & \\
\hline October 28, 2008 & $\begin{array}{l}\text { New Zealand Reserve } \\
\text { Bank }\end{array}$ & \$15b. (Newly signed) & \\
\hline
\end{tabular}


Table 1. (Continued)

\begin{tabular}{|c|c|c|c|}
\hline Time of Announcement & $\begin{array}{c}\text { Participating Central } \\
\text { Banks }\end{array}$ & Amount & Term \\
\hline October 29, 2008 & $\begin{array}{l}\text { Central Bank of Brazil } \\
\text { Central Bank of Mexico } \\
\text { Bank of Korea } \\
\text { Monetary Authority of } \\
\text { Singapore }\end{array}$ & $\begin{array}{l}\text { \$30b. (Newly signed) } \\
\$ 30 \text { b. (Newly signed) } \\
\text { \$30b. (Newly signed) } \\
\text { \$30b. (Newly signed) }\end{array}$ & $\begin{array}{l}\text { Extended to } \\
\text { April 30, } \\
2009\end{array}$ \\
\hline $\begin{array}{c}\text { February 3, } 2009 \text { and } \\
\text { June 25, } 2009\end{array}$ & $\begin{array}{l}\text { All the } 14 \text { above-men- } \\
\text { tioned central banks }\end{array}$ & $\begin{array}{l}\text { Aggregate amount up } \\
\text { to } \$ 640 \mathrm{~b} \text {. }\end{array}$ & $\begin{array}{l}\text { Extended first } \\
\text { to October } \\
30,2009 \\
\text { and later to } \\
\text { January 31, } \\
2010\end{array}$ \\
\hline May 9, 2010 & $\begin{array}{l}\text { European Central Bank } \\
\text { Switzerland National Bank } \\
\text { Bank of England } \\
\text { Bank of Japan } \\
\text { Bank of Canada }\end{array}$ & $\begin{array}{l}\text { Indefinite amount limit, } \\
\text { swap as required }\end{array}$ & 3 years \\
\hline October 31, 2013 & Same as above & $\begin{array}{l}\text { Indefinite amount and } \\
\text { term limit, swap as } \\
\text { required }\end{array}$ & Permanent \\
\hline
\end{tabular}

Sources: The U.S. Federal Reserve: Central Bank Liquidity Swaps, http://www. federalreserve.gov/monetworkarypolicy/bst_liquidityswaps.htm; and Linda S. Goldberg, Craig Kennedy and Jason Miu, "Central Bank USD Swap Lines and Overseas USD Funding Cost," FRBNY Policy Review, May 2011.

\section{Global or regional} financial crises tend to transform currency swaps from temporary measures of market intervention into more institutional arrangements. with the purpose of fighting market turbulence through increasing foreign exchange supplies. With the outbreak of the Southeast Asian financial crisis in 1997, these short-term and annually revisited agreements developed into the "Chiang Mai Initiative" which included the ten ASEAN members, China, Japan and South Korea. Under the "Chiang Mai Initiative," a set of bilateral currency swap sub-agreements were signed and the swap amount was greatly increased. At present, these bilateral agreements have evolved into multilateral agreements, with the funding scale extended to $\$ 240$ billion. 
It is notable that most currency swaps are conducted between the USD and other national currencies, as the USD remains the most significant international reserve currency. However, since the 2008 global financial crisis and the European debt crisis demonstrated the volatile value of the USD as well as the Euro, some countries have begun to mitigate the risk by diversifying their reserve currencies. Some non-mainstream currencies especially from major developing countries have started to play a bigger role in currency swap transactions and are held by increasing central banks. In this context, some countries concluded currency swap agreements with their national currencies as direct swap objects. For example, On June 25, 2012, the central banks of Switzerland and Poland signed a swap agreement between the Swiss Franc (CHF) and the Poland Złoty (PLN); on December 4, 2012, India and Japan signed a three-year swap agreement with the amount equivalent to US $\$ 15$ billion. China's RMB also joined in bilateral currency swaps during the process of RMB internationalization. The decentralized role of the USD and increasing significance of other currencies in the international reserve system will inevitably contribute to the international financial reform.

\section{Can USD-centered Currency Swaps Promote the International Financial Reform?}

The evolution of currency swaps from short-term expediencies to more institutional arrangements has attracted worldwide attention from both market players and academia. Does this suggest that financial turmoil or crises have become a normal phenomenon? Or that credit issuers (usually referring to central banks) increasingly demand cross-border currency transactions? Or that central banks are trying to enhance international financial governance with their national currencies?

The U.S. Federal Reserve has long been considered as the pioneer and advocate of currency swaps, whose action is justified by many supporting theories. For example, scholars from the Federal Reserve thought the USD supply shrank dramatically in the global financial market after the 2008 financial crisis, ${ }^{5}$ and the Federal Reserve, through its many swap deals,

\footnotetext{
${ }^{5}$ Michael J. Fleming and Nicholas J. Klagge, “Federal Reserve's Foreign Exchange Swap Lines," Current Issues in Economics and Finance, Vol. 14, No. 4 (April 2010), https://www. newyorkfed.org/medialibrary/media/research/current_issues/ci16-4.pdf.
} 
promptly provided USD liquidity to other Western countries, greatly alleviating the pressure on them. According to research done by the Federal Reserve, when the market is in shrinkage, it is necessary for the Federal Reserve to provide extra liquidity to the market by currency swaps so as to avoid further crisis shocks, ${ }^{6}$ regardless of the causes and negative impacts of the financial crisis.

Mainstream economists and scholars in the U.S. generally hold a positive attitude toward currency swaps. Edwin M. Truman, for instance, points out that a currency swap network among global central banks should be established and should play the role as lender of last resort if crises constantly break out. ${ }^{7} \mathrm{He}$ also suggests that this network be further divided into three levels: the first is the IMF which can initiate or recommend member central banks to conclude swap arrangements; the second is the present central bank group (of the six major developed economies) which should conduct swap transactions based on their own standards and judgments; and the third level lies in individual central banks which can make currency swap deals based on bilateral requirements.

Christopher Destais thinks that the above-mentioned currency swap network might not be the best choice, though it remains a sub-optimal choice to provide required liquidity when the market suffers from a serious crisis. ${ }^{8} \mathrm{He}$ also argues that the global currency swap network could generate far more positive functions than negative ones if related central banks insist on the principle of transparency. Therefore, he suggests the Group of Twenty (G20) issue specific regulations for currency swaps of central banks to ensure transparency and avoid moral hazards. ${ }^{9}$

${ }^{6}$ Linda S. Goldberg, Craig Kennedy, and Jason Miu, “Central Bank USD Swap Lines and Overseas USD Funding Cost," FRBNY Policy Review, May 2011, https://www.newyorkfed.org/medialibrary/media/research/epr/11v17n1/1105gold.pdf.

${ }^{7}$ Edwin. M. Truman, “Enhancing the Global Safety Network through Central Bank Cooperation," VoxEU.org, September 10, 2013, http://www.voxeu.org/article/enhancingglobal-financial-safety-net-through-central-bank-cooperation.

${ }^{8}$ Christopher Destais, "The International Monetary System as a Swap Nexus," presented at Think 20 Meeting at Sydney, Australia, December 11, 2013.

${ }^{9}$ Christopher Destais, “Central Bank Currency Swap and International Monetary System," CEPII Policy Brief, No. 5 (September 2014), http://www.cepii.fr/PDF_PUB/pb/2014/ pb2014-05.pdf. 
From the perspective of stabilizing the international financial market, Maurice Obstfeld and many others believe that when a bank run or capital flight happens in a country, the reserve level of this country is an important indicator to judge how much the domestic currency exchange rate will depreciate, and it is far from enough to only consider the deficit scale of the current account. Therefore, they argue that the currency swap scale provided by the Federal Reserve is also a reserve line which has the same function of stabilizing the exchange rate as a standby foreign exchange reserve. $^{10}$

Nevertheless, there are also some differing evaluations on the functions of currency swaps among Western central banks centered on the U.S. Federal Reserve. Some argue that the significance of the currency swaps is relatively limited, since their contribution to maintaining a country's foreign exchange reserve has proven only marginal. ${ }^{11}$ Others think that currency swaps of central banks during a serious crisis are likely to generate positive results, yet if they are extended indefinitely in time or amount limits, they might trigger a number of problems including: (1) the risk of losing monetary policy independence; (2) moral concerns in helping domestic financial institutions; and (3) the risk of having a few Western central banks dominate the status of international lender of last resort. ${ }^{12}$

Although U.S. economic power has been on a relative decline, the status of the USD as the major stabilizer of the international financial

${ }^{10}$ Obstfeld, Shambaugh and Taylor, "Financial Instability, Reserves and Central Bank Swap Lines in the Panic of 2008."

${ }^{11}$ Catharina J. Hooyaman, "The Use of Foreign Exchange Swaps by Central Banks," IMF Staff Paper, Vol. 41, No. 1 (March 1994), pp. 149-146.

${ }^{12}$ Francesco Papadia, "Central Bank Cooperation during the Great Recession," Bruegel Policy Contribution, No. 8 (June 2013), http://bruegel.org/wp-content/uploads/imported/ publications/pc_2013_08.pdf; Destais, “Central Bank Currency Swap and International Monetary system"; Ian Talley, "In Face-off, Fed's Keeping the IMF Out of Its Currency Swap Domain," Wall Street Journal, May 22, 2014, http://blogs.wsj.com/economics/2014/05/22/inface-off-feds-keeping-the-imf-out-of-its-currency-swap-domain/; Andrew Sheng, "Central Bank Currency Swaps Key to International Monetary System," East Asian Forum, April 1, 2014, http://www.eastasiaforum.org/2014/04/01/central-bank-currency-swaps-key-to-international-monetary-system/. 
market remains unchallenged. The Euro, British Pound, Japanese Yen, Canadian dollar and Swiss Franc issued by the other five Western central banks can hardly replace the role of the USD in the diversified monetary system. Because of the USD hegemony, currency swap deals seem to have become a kind of passive choice for these five central banks.

Economists hold divergent views on the functions of currency swaps among Western central banks.

Shen thinks that the real purpose of currency swaps between the U.S. Federal Reserve and the other five central banks is to safeguard their own benefits in addition to maintaining market stability, yet this selfinterested behavior may cause even more turbulence to the international monetary system. Rhee and others argue that regional currency cooperation and the currency swaps of some central banks cannot replace broader international cooperation. Different benefit orientations and cooperation mechanisms of the participants may not be consistent with transparency and stability required by the global financial system. Therefore, cooperation with regard to macro-economic policy and market supervision on the global level is most urgently needed..$^{13}$ Destais also argues that currency swaps among Western central banks need to strictly follow rules of transparency and execution conditions based on the G20 framework. ${ }^{14}$

Chinese scholars have also paid great attention to the currency swaps of central banks of the six Western economies. Analysts from the People's Bank of China (PBOC) such as Guan Tao and Ma Jun tend to hold a positive view. In their eyes, such currency swaps were mainly intended to increase the supply of market liquidity, which is generally beneficial to the global financial system. Since the IMF was then powerless to act in a timely fashion, they argue, it was both necessary and wise for the six Western economies to employ those currency swaps to stabilize the international

${ }^{13}$ Changhyong Rhee, Lea Sumulong, and Shahin Vallee, “Global and Regional Safety Network: Lessons from Europe and Asia," Bruegel Working Paper, November 2013, http:// bruegel.org/wp-content/uploads/imported/publications/WP_2013_02.pdf.

${ }^{14}$ Destais, “Central Bank Currency Swap and International Monetary System." 
financial market. From this perspective, China should join the U.S.-dominated swap system under suitable conditions. ${ }^{15}$

In a similar tone, Jin Zhongxia proposes that the temporary bilateral agreements established after the financial crisis have gradually become multilateral and institutionalized. The main effects of these agreements include: (1) stabilizing the international financial markets; (2) maintaining the USD's status as the major reserve currency; (3) reinforcing the existing pattern of the international monetary system; and (4) enhancing global financial governance. ${ }^{16} \mathrm{Xu}$ Yisheng argues that the U.S. Federal Reserve-centered currency swap network provides a new model to overcome future financial crises, though its exclusion of developing countries in selecting swap partners should be criticized. Believing that a currency swap between China and the U.S. could launch another chapter in their "new-model major-power relationship," he suggests China be more active in discussing with the U.S. about joining the USD swap network. ${ }^{17}$

Such thoughts are shared by some other scholars. Li Yang, for example, argues that the currency swaps of central banks of the six Western economies is the prototype of a new international financial system, thus China should try to get involved rather than be left outside. ${ }^{18}$ As Zhang Monan observes, "the monopoly mechanism of the Federal Reserve as the lender of last resort has been enhanced by the currency swap agreements of six

${ }^{15}$ Guan Tao's and Ma Jun's views can be found in the summary report of the views and comments expressed during a seminar on the "Interpretations and Implications of Central Bank Currency Swap and Regional Financial Arrangement" organized by the Shanghai Development Research Foundation on September 27, 2014, in Shanghai, http://www.sdrf. org.cn/upfile/Upload/ytsl/59.pdf.

${ }^{16}$ Jin Zhongxia's view can be found in the same summary report on the seminar on the "Interpretations and Implications of Central Bank Currency Swap and Regional Financial Arrangement."

${ }^{17} \mathrm{Xu}$ Yisheng, "Emerging Market Should Test Fed Currency Swap," International Investment Forum website, August 15, 2013, http://www.chinafair.org.cn/china/investweb/ NewsMore.aspx?newid $=40722$.

${ }^{18} \mathrm{Li}$, “Yige dui Zhongnanhai Butai Youhao de Jingji Tongmeng zheng Xingcheng [An Economic Union Unfriendly to Zhongnanhai is Forming]." 
central banks. The U.S. is building a new monetary union targeting the rise of currencies of emerging economies." Therefore, he suggests that

China should positively participate in the 'bilateral swap network' led by the U.S. Even though China holds US\$3.95 trillion in its foreign exchange reserves, swapping currency with the Federal Reserve will make us more flexible when capital outflow occurs, just like Japan.... BOC should also inquire the possibility of conducting currency swap with the Federal Reserve. ${ }^{19}$

All these positive comments are based on reasonable assessment. It is self-evident that the currency swaps among Western central banks would provide extra liquidity and thus help stabilize the international financial market when a serious crisis strikes the world economy. But it would be naïve for world economies to laud such arrangements without taking heed of their potential negative effects. One might expect a new, healthier international financial system to develop out of a multi-level currency swap network of central banks, but the currency swaps among Western central banks can hardly contribute to such a system, as their ultimate purpose is to strengthen the USD dominance rather than promote international financial reform. As a matter of

The USD-centered

currency swaps are not helpful to the international financial reform even with more countries joining the swap network. fact, such swap deals set up more obstacles to the reform, for they provide extra standby liquidity outside the IMF system, and the agenda of IMF quota reform is thus delayed and even shelved. In December 2010, the U.S. Congress vetoed the IMF decision to propose an alternative option to increase liquidity. As a result, only a very limited number of currencies of emerging countries can perform the function of value measurement in international transactions.

${ }^{19}$ Zhang Monan, "Do Our Utmost to Win Active Space in the New Global Currency Framework," Shanghai Securities News, June 26, 2014. 
Since the currency swaps among central banks of the six Western economies are made to maintain the current international financial system and the USD dominance in particular, they cannot overcome the following defects in the system: (1) As the key international currency, the value of the USD fluctuates in accordance with the U.S.' economic needs and national interests, which will inevitably result in constant shocks and crises; (2) The fluctuation of exchange rates between major international currencies, as well as the monetary policy adjustment of the U.S. Federal Reserve, often leads to rapid changes of global liquidity, thus generating instability of the international financial market; ${ }^{20}$ and (3) Rules are still lacking in adjusting the imbalance of international payment. In this light, the currency swaps among central banks of the six Western economies can hardly promote the international financial reform. The U.S. even considers it necessary to slow the capital expansion of the IMF, and the U.S. Congress failed to pass the resolution in 2010 to increase shares for IMF board of directors or adjust shares for IMF member countries.

Without setting quotas, the currency swaps among central banks of the six Western economies have theoretically provided a green channel and a relatively flexible fund pool for one of these central banks to borrow money from others, especially in time of a crisis. However, as some scholars correctly observe, such currency swaps are likely to be kidnapped by irresponsible monetary policies from a single central bank if no strings are attached to the loan. Moreover, if potential moral hazards are not well-managed, such currency swaps would either compel each central bank to increase its money supply, which aggravates domestic inflation, or to refuse the constant injection of liquidity, which undermines the actual effects of the swaps.

${ }^{20}$ Helene Rey, "Dilemma not Trilemma: The Global Cycle and Monetary Policy Independence," Economic Policy Symposium Proceedings (Kansas City: Federal Reserve Bank of Kansas City, 2013), https://www.kansascityfed.org/publicat/sympos/2013/2013Rey.pdf; Cesa-Bianchi, Ambrogio, Luis Felipe Cespedes, and Alessandro Rebucci, "Global Liquidity, House Prices, and the Macroeconomy: Evidence from Advanced and Emerging Economies," IMF Working Paper No. 15/23 (Washington D.C.: IMF, 2015). 


\section{The Significance of RMB Swaps to the International Financial Reform}

Thanks to its much wider use in cross-border trade activities, the RMB has become the seventh biggest transaction currency and the fifth biggest payment currency in the world. Today, the offshore markets of the RMB have extended from Hong Kong to London, Frankfurt, Singapore and Seoul, and a global RMB payment and settlement system is taking shape. On the other hand, the RMB is not yet fully convertible on the international financial market. Currently, the major approach to acquire the RMB is by doing business with Chinese enterprises. Foreign central banks have few channels to obtain the RMB other than borrowing it or issuing RMB bonds in Hong Kong or other offshore RMB markets. Against this backdrop, currency swap agreements with the RMB provide a promising alternative. So far, most of these swap agreements have been temporary with the purpose of combating financial turbulence instead of channeling the RMB into the international market. In this regard, promoting RMB internationalization through currency swaps could only generate some indirect impacts. In addition, one should not ignore the potential risks posed by RMB swaps. Most notably, some of the currency swap agreements signed between the PBOC and foreign central banks have not been fully implemented. With a growing number of central banks involved in RMB swaps, it might be more difficult for them to employ RMB swap funds as long-term credit, which may cause imbalance of payments and create negative effects on their foreign exchange reserves. If RMB swaps are used for long-term purposes, the lack of corresponding guarantee may also lead to frequent defaults.

Nevertheless, RMB swap agreements between the PBOC and other central banks have boosted the further use of the RMB by foreign enterprises and individuals, which helps build up the image of the RMB as a popular currency for international transaction. Over the past few years China has signed currency swap agreements with 33 foreign central banks, with a total amount of 3.3 trillion Yuan. The first such deal was made with South Korea in December 2008 in the form of domestic currency worth RMB 180 billion/Korean Won 38 billion. In order to promote bilateral trade, this agreement was renewed in 2011, with its amount expanded to 360 billion Yuan. As a vital step of RMB internationalization, the currency swaps 
between the PBOC and 33 foreign central banks have encouraged those countries to hold RMB assets and laid a solid foundation for the RMB to evolve from an international settlement currency into a reserve currency.

The currency swaps between the PBOC and foreign central banks are of lasting significance to the international financial reform.

First, they help reduce the USD dominance in the existing international currency swap network and enhance the voice of emerging countries in the international financial system. Despite the exclusive currency swap arrangements among Western central banks and their reluctance toward the international financial reform, the currencies of emerging economies will inevitably play a Despite their limited effect to promote $\mathrm{RMB}$ internationalization, RMB swaps led by the PBOC will exert lasting impact on the international financial reform. bigger role in bringing more balance and diversity to the global financial market.

Second, although the currency swap arrangements made by the PBOC are generally small in scale compared with those among Western central banks, they have involved more partners. This kind of inclusiveness has received positive feedback from the international community, which better demonstrates that the international financial reform should satisfy the needs and interests of the majority of countries in the world.

Third, the currency swaps made by the PBOC or other financial institutions such as the New Development Bank, Emergency Reserve Fund of BRICS, and Asian Infrastructure Investment Bank (AIIB) will continue generating new momentum to the reform of the international financial system. While the U.S. continues to monopolize agenda-setting and rulemaking power in the world, it has no other choice but to adapt to the changing realities and be more accommodative to the collective needs of developing countries in establishing a more inclusive and balanced international financial system.

In a word, the PBOC-led RMB swaps and the USD swaps made by the U.S. Federal Reserve are both transitional measures in the process of the international financial reform. While neither alone can solve existing problems or defects in the international financial system, they reflect the urgent need to build new mechanisms for broader international cooperation. 
Looking into the future, the international community should advance cooperation between developed and emerging economies based on the traditional approach of the IMF as well as the more recent G20 platform. To safeguard a stable international monetary and financial system, improving regulations and institutions should become a priority of global financial governance.

\section{Conclusion}

Developed and developing countries naturally have different opinions on how to maintain stability and enhance vitality of the global financial system. In time of crisis, the U.S. Federal Reserve and other five Western central banks played a constructive role in stabilizing the global market by weaving a currency swap network outside the IMF system, yet their main purpose was to consolidate the current international financial system rather than launch a systematic reform to it. Therefore, the intrinsic defects of the system will remain until the next global financial crisis takes place.

For this reason, the currency swap network led by the U.S. Federal Reserve only provides limited safety to the international financial market, which will hardly help when serious market turmoil occurs again, especially in developing countries largely dependent on the IMF and other bilateral arrangements for required liquidity. In this sense, the IMF remains irreplaceable in the current international financial structure. Meanwhile, the U.S. has held a very conservative view toward including more members in particular those emerging economies - into the Federal Reserve-led currency swap network. ${ }^{21}$ With regard to the U.S. predominance in the IMF, developing countries may find it difficult to obtain from the IMF the liquidity support they urgently need.

RMB swaps promoted by the PBOC play a similar role in coping with market turbulences, while they could decentralize the role of the USD and provide another alternative for developing countries other than the selective currency swaps of the U.S. Federal Reserves. RMB swaps may also serve as a shortcut for RMB internationalization, for some countries have begun to adopt the RMB as a reserve currency. Nevertheless, one should not

${ }^{21}$ In 2008, the U.S. Federal Reserve rejected the swap requirements proposed by Peru. Developing countries are usually not qualified to join currency swaps after examination and approval conducted by the Federal Reserve. 
overestimate the role of RMB swaps in pushing forward the international financial reform. Before the RMB becomes a real international currency, RMB swaps will only play a complementary role to the currency swaps among Western central banks, and their contribution to stabilizing the global financial market will remain very limited. 